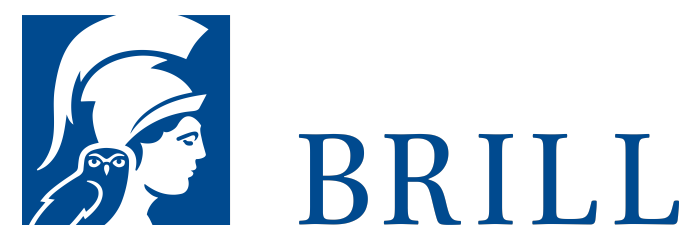

\title{
Roosevelt und Hitler
}

Todfeindschaft und totaler Krieg

Author: Ronald D. Gerste

30. Januar 1933: Adolf Hitler kommt an die Macht. 4. März 1933:

Franklin Delano Roosevelt wird als 32. amerikanischer Präsident vereidigt. In den nächsten 12 Jahren wird sich zwischen dem Diktator und dem Demokraten eine Rivalität entwickeln, die über das Schicksal Deutschlands, Europas und der Welt entscheiden wird.

U-Boote im Nordatlantik, Bombenkrieg gegen deutsche Städte, die Invasion in der Normandie, die Befreiung Westeuropas, der Konzentrationslager und auch der Deutschen durch amerikanische Soldaten, schließlich die Besetzung des größten Teil Deutschlands durch die Westalliierten: Der Konflikt zwischen Deutschland und den USA war ein zentrales Geschehen des Zweiten Weltkrieges und legte die Grundlage für das Nachkriegseuropa. Dieser Krieg ist auch die Geschichte einer persönlichen Feindschaft zwischen dem amerikanischen Präsidenten Franklin D. Roosevelt und Adolf Hitler. Dieses Buch, teils Biografie, teils Zeitgeschichte, erzählt auf spannende Weise vom Ringen eines Präsidenten, der als Politiker und Mensch seine Fehler hatte - dem jedoch die historische Größe zugesprochen wird, mit aller Entschlossenheit gegen das Übel des Faschismus und des Nationalsozialismus vorzugehen gegen den Mann, der über Europa die Finsternis der Diktatur und des Holocaust niedergehen lassen wollte.

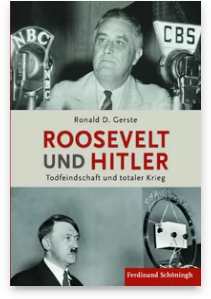

Pages: 312 Seiten, $16 \mathrm{~s} / \mathrm{w}$ Abb.

Language:

German

Subjects:

Modern History, History

Publisher: Brill |

Schöningh

E-Book (PDF)

Released online: O2 Jan 2012

ISBN: 978-3-

657-77088-5

List price

USD $\$ 52.00$

Hardback

Publication date: og Mar 2011

ISBN: 978-3506-77088-2

List price

USD $\$ 52.00$ 
Ronald D. Gerste, geb. 1957, Studium der Humanmedizin und Geschichte an der Universität Düsseldorf; er schreibt für zahlreiche Zeitungen und wissenschaftliche Zeitschriften. Seit 2001 lebt er als hauptberuflicher Wissenschaftskorrespondent und Sachbuchautor in Washington, D.C.

For more information see brill.com

Order information: Order online at brill.com +44330 333 oo49 | customerservices@brill.com Submission information: brill.com/authors

Titles published by Brill | Fink, Brill | mentis or Brill | Schöningh: +49(o)71 5413279216 | brill@brocom.de 